\title{
OPTIMALISASI PEMBELAJARAN AKIDAH BERBASIS TEKNOLOGI DI MASA PANDEMI
}

\author{
Indah Khairunnisa 1$) *$ \\ Yazida Ichsan ${ }^{2)}$ \\ Nikmatin Muyasaroh ${ }^{3)}$ \\ Muhyidin 4) \\ Hafiz Atha Muhanna 5) \\ 1, 2, 3, 4, 5 Program Sarjana Pendidikan Agama Islam, \\ Universitas Ahmad Dahlan Yogyakarta \\ *E-mail: indah1900031192@webmail.uad.ac.id
}

\begin{abstract}
Departing from the covid-19 pandemic that is hitting humans today, all sectors of life seem to be experiencing shocks, especially education. The learning process that should be carried out directly between teachers and students, has now been transferred to an online system. The existence of major changes in the current education system has forced teachers to mobilize all their potential as educators by teaching using technology. Especially faith education, teachers are required to be able to provide faith education to their students as in face-to-face learning in the past. This is of course a new responsibility for teachers. However, in this limited condition, the teacher's work will be greatly helped by the support from the parents who are always by their children's side. It is a joint task between teachers and parents in optimizing the process of creed education to students.
\end{abstract}

Keywords: Creed, Technology, and Pandemic

\begin{abstract}
Abstrak
Berangkat dari pandemi covid-19 yang melanda manusia saat ini, segala sektor kehidupan seakan mengalami ketergoncangan, terutama pendidikan. Proses pembelajaran yang seharusnya dilakukan dengan secara langsung antara guru dan peserta didik, sekarang hal itu sudah dialihkan dengan sistem online. Adanya perubahan besar dalam sistem pendidikan yang berlaku membuat para guru untuk mengerahkan segala potensi sebagai seorang pendidik dengan megajar menggunakan teknologi. Khususnya pendidikan akidah, guru dituntut agar mampu memberikan pendidikan akidah kepada peserta didiknya sebagaimana pada pembelajaran tatap muka pada sebelumnya. Hal tersebut tentu saja menjadi tanggung jawab baru bagi para guru. Namun dalam kondisi yang terbatas ini, pekerjaan guru akan sangat terbantu dengan adanya dukungan dari wali murid yang senantiasa berada di sisi anakanaknya. Menjadi tugas bersama antara guru dan orang tua dalam mengoptimalkan proses pendidikan akidah kepada para peserta didik.
\end{abstract}

Kata Kunci: Akidah, Teknologi, dan Pandemi

\section{PENDAHULUAN}

Sebuah proses dilakukan dengan rencana dan tujuan atas kebijakan merupakan hal yang dapat mendasari keberhasilan sebuah pendidikan. Pendidikan merupakan sebuah pondasi bangsa yang dapat menciptakan generasi yang berkualitas dan cendikiawan yang suatu saat akan menjadi penerus bangsa. Proses belajar mengajar 
yang diadakan disekolah sebagai pembelajaran formal sebagai upaya dalam membentuk sebuah perubahan secara kognitif pada individu setiap siswa, afektif dan psikomotorik siswa dalam interaksi biasanya dipengaruhi beberapa hal seperti interaksi antara pendidik, peserta didik, materi pembelajaran, lingkungan, metode pembelajaran dan saran prasarana. Tujuan utama sebuah pendidikan yaitu menciptakan generasi yang memiliki nilai intelektual yang berkualitas dan dapat membentuk jiwa yang bersih dan berakhlak mulia (Hadarah 2020).

Melihat situasi yang kurang stabil pada saat ini yang dialami oleh seluruh negara di belahan dunia yang sedang menghadapi bawah covid 19 dan menimbulkan dampak negatif terhadap kegiatan manusia. Dampak yang di sebabkan covid 19 salah satunya yaitu penghambatan proses belajar mengajar yang biasanya dilakukan secara luring kini dilakan secara daring dengan bantuan media teknologi. Pada umunya guru melakukan kegiatan belajar mengajar secara luring yang umunya dilakukan dengan metode ceramah namun dikarenakan melihat situasi saat ini pembelajaran dilakukan secara virtul yang dapat menjadikan salah satu hambatan terhadap sekolah jika pada sebelumnya belum pernah menggunakan bantuan media teknologi dalam proses belajar mengajar (Giyarsi 2020).

Dalam mengembangkan atau mengoptimalkan proses pendidikan khususnya untuk pendidikan akidah, seorang guru dituntut untuk lebih kreatif lagi dalam menanamkan nilai akidah kepada para peserta didiknya. Menjadi hal baru bagi pafa guru sekarang, memberikan pendidikan akidah dengan teknologi dan proses online. Namun, seorang guru yang profesional tidak akan pernah kehilangan ide untuk mendidik peserta didikya meski dalam kondisi apapun. Harapannya, dengan hubungan dan kerja sama yang baik antara guru dan wali murid, diharapkan tujuan pendidikan akidah yang hendak dicapai di masa pandemi ini dapat dicapai dengan sempurna.

Ada banyak kendala pandemi, seperti efektivitas teknologi pembelajaran. Banyak teknologi termasuk teknologi pembelajaran yang membantu, seperti Zoom, Google Meet, WA group, dan Classroom. Namun, selama proses pembelajaran, Anda mungkin menemui banyak kendala seperti kendala terkait aplikasi yang Anda gunakan, efisiensi aplikasi dan jaringan yang digunakan oleh aplikasi tertentu, dan lain-lain. Hal ini penting dalam proses pembelajaran, terutama di masa pandemi saat ini. Proses penggunaan teknologi pembelajaran lebih sederhana dan efektif, sehingga memudahkan siswa dalam mendapatkan materi. 
Penelitian dalam jurnal ini memaparkan bagaimana mengoptimalkan efektivitas pembelajaran teknologi selama pandemi untuk kenyamanan dan tentunya penyampaian materi pendidikan akhlak ditinjau dari berbagai teknologi pembelajaran atau learning. Mengapa harus ditekankan dalam pemilihan teknologi, karna kita tahu bahwasannya proses belajar disaat online ini harus tepat didalam memilih aplikasi atau teknologi yang seefisien mungkin. Dengan memilih teknologi yang efisien maka akana timbul kenyamanan dalam belajar online dan akan memperlancar jalannya proses pembelajaran.

Mengetahui masalah atau kendala dimasa pandemi ada hal yang harus diperhatikan lainnya yaitu mengenai masalah kendala baik sinyal maupun aplikasi tersebut didalam berlangsungnya suatu pembelajaran. Jelas sudah bahwasannya suatu aplikasi tentunya mempunyai kelebihannya masing-masing, dan kelebihan keukurangan tersebut harus menjadi sebuah pertimbangan didalam berlangsungnya proses pembelajaran. Jangan sampai menggunakan aplikasi pembelajaran di dalam proses berlangsungnya pembelajaran akan menyusahkan murid, mahasiswa, dan lainlain. Sebagai guru atau dosen yang profesional maka dituntut aktif dalam memilah dan memilih teknologi mana yang sesuai dan dapat dijangkau oleh peserta didik, serta juga melalui peninjauan dari segi efisiensi dalam berlangsungnya pembelajaran.

Mengetahui efisiensi pengggunaan teknologi dimasa pandemic Untuk pembelajaran pendidikan aqidah akhlak, tentulah merujuk kepada pembentukan karakter. Maka dari itu pelajaran aqidah akhlak mungkin hanya sebatas pengoptimalan didalam proses pembelajaran. Kita tahu bahwasannya teknologi tidak dapat memantau dua puluh mempat jam jam siswa, maka sesungguhnya akhlak terbentuk dari bawaan dan bisa dari lingkungan keluarga atau masyarakat. Akan tetapi dengan ditekankan kepada materi siswa dapat merenungkan dan menyerap ilmu dengan luas sehingga memunculkan sebuah kesadaran diri sendiri. Ini semua membutuhkan suatu teknologi yang efisien yang memudahkan siswa dalam menyerap ilmu dan ini akan dalam ditinjau nantinya didalam sebuah pembahasan.

Lahirnya pandemi covid-19 menjadi sebuah peralihan sistem pembelajran terhadap siswa mulai dari pendidikan PAUD sampai mahasiswa sehingga pandemi ini mengalihkan pembelajaran peserta didik yang biasanya pembelajaran dilakukan secara tatap muka didalam kelas (luring) menjadi pembelajaran secara online dengan bantuan media aplikasi (daring). Tidak hanya itu pandemi ini juga menyebar 
keberbagai negara termasuk indonesia. Dalam kasus ini menyebabkan dampak beberapa sektor slah satunya pada Pendidikan (Muhaini, 2019).

Peran media sangat penting dalam prosesnya pembelajran, diman jika materi yang disampaikan masih mengandung ketidakjelasan dapat dibantu oleh media sebagai alat perantara. Dengan bantuan media juga keminiman bahan ajar yang hendak digunakan untuk disampaikan dapat ditunjang dengan bantuan media. Semakin canggihnya teknologi-teknologi dapat memudahkan dalam segala hal termasuk dalam pembelajran. Dengan alat bantu tersebut diharapkan dapat memudahan peserta didik ataupun pendidik dalam menyapaikan materi dan diharapkan pembelajran akan lebih menarik, lebih kongkrit, mudah dipahami juga menghemat waktu.

Dalam permasalah yang ada makan teknologi sangat berperan penting dalam pelaksanaan pembelajaran dimasa pandemi covid-19. Selain itu media teknologi juga sebagai alat bantu dalam bahan pembelajran yang tahap orientasinya akan sangat membantu keekfektifitasan dalam belajar, penyampaian pesan dan isi dari pembelajaran tersebut. Dan dapat membangkitkan minat belajar dan motivasi peserta didik dalam belajar, meningkatkan pemahaman, menambah informasi dan tentunya mempermudah dalam mengakses materi-materi yang lebih akurat (Muammar \& Suhartina, 2018).

Tujuan dari artikel ini sesungguhnya ialah untuk mengetahui teknologi yang efesien dalam pembelajran dimasa pandemi dan dapat memberi motivasi terhadap peserta didik selama pembelajaran khususnya terhadap guru ataupun dosen dalam kegiatan belajar mengajar adapun beberapa teknologi learning yang harus dikaji dalam proses pembelajaran diantaranya yaitu ada, zoom meeting, google meet, class-room, google spred sheet, Whats-App dan sebagainya. Untuk mengetahui aplikasi tersebut seberapa efesien dalam pembelajaran khususnya pembelajaran akidah maka harus membuat analisa terlebih dahulu agar dapat mengetahui kelebihan dan kekurangan aplikasi tersebut jika digunakan dalam pembelajaran.

\section{METODE}

Metodologi yang digunakan dalam penilitian ini yaitu menggunakan metode kualitatif. Data ini diambil dari sumber pustaka berupa sumber buku dan dari jurnal atau artikel terkait. Data terlebih dahulu dikumpulkan, kemudian diambil ringkasan dari jurnal maupun artikel. Setelah itu dijabarkan secara deskriptif. Dalam penelitian 
Optimalisasi Pembelajaran Akidah berbasis teknologi di masa pandemi ini, peneliti juga melihat secara langsung keadaan masalah mengenai yang terkait, lalu menelaah kembali jurnal agar sesuai dengan solusi dari permasalahan tersebut.

Dalam sebuah penelitian optimalisasi pembelajaran dikala pandemi ini, peneliti mencoba memahami konsep dengan melihat berbagai problema yang terjadi. Peneliti juga mencoba menganalisa aplikasi pembelajaran yang terkait sebagai rujukan nantinya didalam daring. Penelitian ini juga menjelaskan secara deskriptif berbagai problema serta keefektifan aplikasi didalam daring.

\section{HASIL DAN PEMBAHASAN}

\section{Model Pembelajaran Pendidikan Akhlak Berbasis Teknologi di Masa Pandemi}

Pendidikan akidah akhlak dalam pembelajaran merupakan mata pelajaran yang tidak kalah pentingnya dengan mata pelajaran keagamaan yang lainnya. Pendidikan akidah akhlak merupakan mata pelajaran yang dapat membantu dalam pengembangan karakter siswa. Secara umum akidah adalah kepercayaan, keimanan seseorang dan jika dalam Islam akidah adalah kepercayaan seseorang kepada Allah swt atas keesaanya yang menciptakan alam semesta. Sedangkan akhlak adalah sifat atau tingkah laku seseorang yang pada dasarnya tumbuh dalam jiwa manusia yang menumbuhkan tingkah laku atau tindakan spontan yang tanpa adanya pertimbangan. Tujuan pendidikan akidah akhlak adalah untuk menambah dan mengembangkan keimanan siswa dengan akhlak yang terpuji (Wahyudi, 2017).

Model pembelajaran yaitu gambaran atau rancangan yang telah disiapkan oleh guru dari pertama pembelajaran hingga akhir yang bisanya di susun secara praktis atau khas oleh guru. Beberapa model pembelajaran yang lazim dipakai atau dipraktikkan yaitu praktik lapangan, debat, diskusi, ceramah dan sebagainya. Biasanya model pembelajaran ini banyak digunakan dalam kegiatan belajar mengajar secara luring namun model pembelajaran tersebut dapat juga digunakan secara daring dengan bantuan media teknologi yang tersedia (Mardiyah, 2019).

\section{Implikasi Pembelajaran Pendidikan Akhlak Berbasis Teknologi di Masa Pandemi}

Pendidikan akhlak merupakan suatu hal yang sangat urgen dalam menyusuri kehidupan dunia dan menyongsong kehidupan yang abadi di akhirat. Ia menjadi hal yang sangat penting karena dengannya kebangkitan atau kemerosotan nilai pada 
masyarakat salah satunya dinilai dari aspek akhlak atau perilaku. Sampai-sampai dewasa ini, banyak sekali kesenjangan dalam hidup manusia yang tanpa ia sadari penyebab utamanya adalah kurangnya penanaman pendidikan akhlak pada dirinya tersebut. Sebenarnya, tujuan hidup di dunia ini adalah terhindar sejauh-jauhnya dari perbuatan maksiat, tetapi jika diri seseorang sudah dibekali dengan pendidikan akhlak yang bobrok, maka hal tersebutlah yang menjadi sebab utama mudahnya perbuatan maksiat bersemayam di dalam jiwa dan raganya (Rajab, 2021).

Seorang tokoh bernama Fadhil Jamali pernah mengatakan bahwa sebagai seorang muslim yang bertakwa, tugas utama kita adalah menciptakan sistem pendidikan yang memuat pembelajaran keislaman (Gani, 2015). Menjadi tantangan yang siginfikan bagi institusi pendidikan dalam memberikan pendidikan akhlak kepada para siswa. Bahkan, seideal apapun sarana prasarana dan tenaga kerja yang ada dalam suatu institusi pendidikan belum tentu mampu mencapai tujuan pendidikan akhlak (Daheri \& Warsah, n.d.).

Wabah virus corona yang melanda Indonesia membuat perubahan dalam segala sektor kehidapn, termasuk juga pendidikan. Yang mana sebelumnya guru merupakan pusat sentral dalam menanamkan nilai kepada para siswa, maka sekarang pusat sentral itu lebih berpihak pada orang tua yang selalu berada di samping anaknya. Guru dan orang tua sama-sama mempunyai tugas baru. Orang tua mempunyai tantangan baru dalam membimbing pendidikan akhlak anaknya, dan guru senantiasa memastikan keefektifan pendidikan siswa di rumah bersama orang tuanya. Proses belajar mengajar tersebut dapat dilakukan dengan guru memberikan arahan kepada orang tua dalam membimbing siswanya berdasarkan materi pembelajaran yang seharusnya ia sendiri yang sampaikan (Trisnawati \& Sugito, 2020).

Menjadi tugas bersama antara orang tua dan guru dalam menanamkan pendidikan akhlak kepada anak. Apalagi melihat kondisi sekarang yang mana institusi pendidikan tidak mungkin untuk mengadakan pembelajaran dengan sistem tatap muka seperti biasanya. Dengan pembelajaran daring, diharapkan tujuan utama dalam menanamkan pendidikan akhlak yang baik dapat terlaksana dengan semaksimal mungkin. Maka dari itu, sangat diperlukan adanya kerja sama antara guru dan orang tua yang senantiasa ada di rumah mendampingi anaknya. Sebagai orang tua, dalam mengoptimalkan tujuan pendidikan bagi guru, sudah seharusnya mereka dapat membantu kelancaran proses pembelajaran tersebut. Seperti membantu mengawasi 
80 | Indah Khairunnisa, Yazid Ichsan, Nikmatin Musyaroh, Muhyidin, \& Hafiz Atha Muhanna

dan memandu anaknya dalam menggunakan teknologi ketika proses belajar, senantiasa memotivasi anaknya agar memiliki semangat yang tidak pernah memudar, dan lain sebagainya (Harahap dkk., 2021).

Dengan diterapkannya sistem pembelajaran berbasis teknologi di masa pandemi ini, maka diharapkan para pelajar atau siswa senantiasa memiliki rasa kaingin tahuan dan tanggung jawab sebagai pelajar yang terus meningkat. Seiring dengan tujuan tersebut, maka sudah sudah menjadi kewajiban bagi para guru untuk menjaga kestabilan psikologi pelajar agar tidak terganggu. Misalnya, dengan tidak memberikan tugas-tugas yang di luar kemampuan dan jangkauan siswa sehingga membuat ia malas dan muak untuk belajar di kemudian hari. Menjaga kestabilan jiwa pelajar menjadi PR bagi guru. Karena sistem pembelajaran berbasis online tidaklah sama dengan sistem pembelajaran secara tatap muka atau luring (Suherman, 2016).

Maka dari itu, manajemen pendidikan berbasis online berjalan secara kondusif adalah harapan semua orang. Dengan memanfaatkan kecanggihan teknologi yang ada, maka disemogakan mampu menunjang proses pembelajaran sesuai dengan yang diinginkan. Sebagai guru, mereka juga harus selalu memahami perbedaan latar belakang setiap siswa. Hal itulah yang menjadi perhatian utama, kunci dari terciptanya pendidikan akhlak para siswa. Profesionalitas seorang guru akan tampak ketika ia diberi tugas yang mendorong ia untuk berusaha keras. Menanamkan pendidikan dan nilai-nilai akhlak yang baik kepada siswa secara during atau online tidaklah semudah membalikkan telapak tangan. Maka, sistem pengelolaan kelas yang akan mereka pakai nantilah yang akan menentukan berhasil atau tidaknya sistem Pendidikan (Purnomo dkk., 2020).

\section{Problematika Pembelajaran Pendidikan Akhlak Berbasis Teknologi di Masa Pandemi}

Dalam bahasa Inggris, problematika berasal dari kata problematic yang memiliki arti permasalahan. Sedangkan dalam KBBI, problema artinya merupakan sebuah atau suatu hal yang belum dapat diselesaikan yang mengakibatkan permasalahan lain (Zhang D, Zhao JL, Zhou L, 2004), (Asmuni, 2020).

Dari beberapa pendapat tersebut, dapat kita simpulkan bahwasanya pembelajaran merupakan sebuah upaya sadar seorang pendidik guna menumbuhkan minat belajar pada siswa, maksud dari kata belajar disini yaitu adanya pergeseran perilaku pada seorang pelajar dikarenakan adanya kemahiran yang diberlakukan 
dalam jangka waktu yang terbilang lama juga dikarenakan sebuah usaha. Sedangkan pembelajaran daring merupakan pembelajaran yang berbasis teknologi yang dilakukan secara jarak jauh menggunakan media online seperti jejaring internet. Dari pengertian diatas, maka dapat ditarik benang merah bahwasanya problematika belajar mengajar secara daring merupakan persoalan atau permasalahan dalam kegiatan pembelajaran yang dilakukan secara jarak jauh dan menggunakan media online yang dapat menghambat, mempersulit ataupun mengakibatkan kegagalan dalam mencapai tujuan pembelajaran. Agar tujuan pembelajaran daring bisa tercapai dengan maksimal maka permasalahan harus diselesaikan dengan baik dan dengan cara yang tepat (Wahyuningsih, 2021).

Pada masa pandemi covid-19 ini, pendidik bersama peserta didik memiliki tantangan tersendiri dalam menghadapi perubahan dari sistem belajar luring ke sistem during (online). Pelaksanaan pembelajaran daring yang mendadak, menimbulkan berbagai problematika dalam proses pembelajaran daring. Berikut problematika yang dialami dalam proses pembelajaran daring:

a. Materi yang disampaikan dalam pembelajaran daring yaitu melalui media pembelajaran daring membuat pemahaman peserta didik tidak komprehensif.

b. Faktor kompetensi Guru. Kemampuan setiap guru dalam menggunakan teknologi pada pembelajaran daring berbeda. Tidak semua guru mampu mengoperasikan dengan baik, komputer atau gadget untuk pembelajaran daring. Ada guru yang mampu mengoperasikan komputer dengan baik dan ada juga guru yang memiliki kemampuan terbatas dalam mengakses lebih jauh tentang jaringan internet atau penggunaan berbagai aplikasi pembelajaran daring.

c. Keterbatasan guru dalam mengontrol berlangsungnya pembelajaran daring. Hal ini dikarenakan kegiatan proses belajar-mengajar tidak dilakukan secara langsung /tatap muka tapi melalui sistem daring (online) sehingga guru tidak dapat secara langsung mendampingi siswa dalam belajar.

d. Ketiadaan sarana penunjang kegiatan pembelajaran daring. Tidak semua siswa memiliki fasilitas dalam menunjang proses belajar daring seperti komputer, laptop atau smartphone. Dan biasanya smartphone yang digunakan merupakan milik orang tua, sehingga siswa harus bergantian untuk dapat memakainya. Hal ini menjadi masalah jika orang tua siswa sedang bekerja di waktu siswa harus 
melaksanakan pembelajaran daring. Masalah lainnya yaitu perbedaan latar belakang kondisi perekonomian keluarga siswa.

e. Ketiadaan kuota yang dibutuhkan dalam mengakses jaringan internet dalam pembelajaran daring. Kegiatan dalam pembelajaran daring biasanya menghabiskan lebih banyak kuota internet. Hal ini menjadi problem bagi siswa yang terkadang tidak memiliki cukup biaya dalam membeli kuota.

f. Faktor pendekatan pembelajaran. Problem yang dihadapi dalam proses belajar mengajar terjadi karena masalah lingkungan sekitar, orangtua dan pendidikan. Durasi pembelajaran daring yang berlangsung lama membuat siswa merasa bosan dan tak sedikit yang mengalami keluhan fisik seperti mata kelelahan dan lainnya. dan latar belakang keadaan orangtua atau kondisi lingkungan peserta didik juga dapat menghambat kegiatan pembelajaran daring (Juliya \& Herlambang, 2021).

\section{SIMPULAN}

Sebagai seorang muslim, sekedar menikmati dan mensyukuri nikmat dan rahmat yang telah Allah berikan bukanlah batas maksimal dalam berakhlak. Termasuk menghadapi ujian maupun musibah yang datang, bukanlah kesabaran dan kepasrahan yang paling maksimal jika hanya dengan meratapi keadaan. Termasuk juga dalam kondisi kita saat ini. Yang mana seluruh warga Indonesia bahkan dunia sekalipun yang sedang diuji dengan wabah virus corona. Sehingga sangat banyak sektor-sektor kehidupan yang mengalami kepayahan karena keadaan yang berubah, tidak terkecuali pendidikan. Pendidikan akhlak khususnya, dalam kondisi sekarang ini sektor pendidikan pun merancang sistem pembelajaran melalui jarak jauh atau daring. Dengan memanfaatkan teknologi yang ada, maka akan selalu ada ikhtiar yang terjaga selama ada niat pada diri masing-masing pendidikan dan peserta didik.

\section{DAFTAR PUSTAKA}

Asmuni, A. (2020). Problematika Pembelajaran Daring di Masa Pandemi Covid-19 dan $\begin{array}{llll}\text { Solusi Pemecahannya. Jurnal Paedagogy, } 281 . & \end{array}$ https://doi.org/10.33394/jp.v7i4.2941

Daheri, M., \& Warsah, I. (n.d.). ANTARA SEKOLAH DAN.

Gani, A. (2015). Pendidikan Akhlak Mewujudkan Masyarakat Madani. AlTadzkiyyah:Jurnal Pendidikan Islam, 6(November), 273-284. 
Harahap, S. A., Dimyati, D., \& Purwanta, E. (2021). Problematika Pembelajaran Daring dan Luring Anak Usia Dini bagi Guru dan Orang tua di Masa Pandemi Covid 19. Jurnal Obsesi: Jurnal Pendidikan Anak Usia Dini, 5(2), 1825-1836. https://doi.org/10.31004/obsesi.v5i2.1013

Juliya, M., \& Herlambang, Y. T. (2021). Analisis problematika pembelajaran daring dan pengaruhnya terhadap motivasi belajar siswa. Genta Mulia, 12(1), 281-294. https://www.ejournal.stkipbbm.ac.id/index.php/gm/article/view/585

Latifah, A., \& Prastowo, A. (2020). Analisis Pembelajaran Daring Model Website Dan MLearning Melalui Youtube Pada Mata Pelajaran Pai Kelas 2 Sd/Mi. Limas PGMI, 1.

Mardiyah, H. (2019). Pengaruh Model Pembelajaran Make a Match (Mencari Pasangan) Terhadap Hasil Belajar Siswa pada Mata Pelajaran Akidah Akhlak Di Kelas V MI al-Adli Palembang. UIN RADEN FATAH PALEMBANG.

Muammar, M., \& Suhartina, S. (2018). Media Pembelajaran Berbasis Teknologi Informasi dalam Meningkatkan Minat Belajar Akidah Akhlak. KURIOSITAS: Media Komunikasi Sosial Dan Keagamaan, 11(2), 176-188. https://doi.org/10.35905/kur.v11i2.728

Muhaini, H. (2019). Optimalisasi Pendidikan Aqidah Akhlak di Madrasah Ibtidaiyah dalam Membentuk Perilaku Positif Siswa. MODELING: Jurnal Program Studi PGMI, 6(2), 176-185. https://doi.org/10.36835/modeling.v6i2.470

Purnomo, H., Mansir, F., Tumin, T., \& Suliswiyadi, S. (2020). Pendidikan Karakter Islami Pada Online Class Management di SMA Muhammadiyah 7 Yogyakarta Selama Pandemi Covid-19. Jurnal Tarbiyatuna, 11(1), 91-100. https://doi.org/10.31603/tarbiyatuna.v11i1.3456

Rahim, F. R., Suherman, D. S., \& Murtiani, M. (2019). Analisis Kompetensi Guru dalam Mempersiapkan Media Pembelajaran Berbasis Teknologi Informasi Era Revolusi Industri 4.0. Jurnal Eksakta Pendidikan (Jep), 3(2), 133. https://doi.org/10.24036/jep/vol3-iss2/367

Rajab, H. (2021). Pendidikan Akhlak Masa Pandemi. Osfpreprints, 1-4.

Suherman, M. (2016). Efektivitas Strategi Permainan Dalam Mengembangkan SelfControl Siswa. Jurnal Penelitian Pendidikan, 16(2), 194-201. https://doi.org/10.17509/jpp.v16i2.4246

Trisnawati, W., \& Sugito, S. (2020). Pendidikan Anak dalam Keluarga Era Covid-19. Jurnal Obsesi: Jurnal Pendidikan Anak Usia Dini, 5(1), 823-831. https://doi.org/10.31004/obsesi.v5i1.710

Wahyudi, D. (2017). Pengantar Akidah Akhlak dan Pembelajarannya. Lintang Rasi Aksara Books. 
84 | Indah Khairunnisa, Yazid Ichsan, Nikmatin Musyaroh, Muhyidin, \& Hafiz Atha Muhanna

Wahyuningsih, K. S. (2021). Problematika Pembelajaran Daring Di Masa Pandemi Covid-19 Di Sma Dharma Praja Denpasar. Jurnal Pangkaja, 24(1), 107-118.

Zhang D, Zhao JL, Zhou L, J. F. N. (2004). Can classroom replace e-learning learning? Commun ACM, 47(5), 75-79. 